\title{
High Channel Density Ceramic Microchannel Reactor for Syngas Production
}

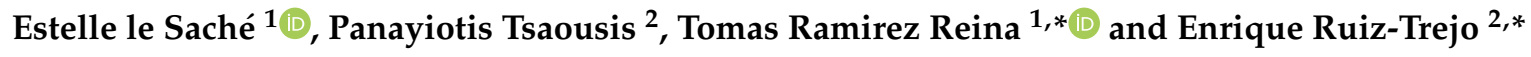 \\ 1 Faculty of Engineering \& Physical Sciences, Chemical \& Process Engineering Department, \\ University of Surrey, Guildford GU2 7XH, UK; estelle.lesache@surrey.ac.uk \\ 2 Smart Separations Ltd., The Technology Centre Surrey Research Park, Guildford GU2 7YG, UK; \\ p.tsaousis@smartseparations.com \\ * Correspondence: t.ramirezreina@surrey.ac.uk (T.R.R.); e.ruiz-trejo@imperial.ac.uk (E.R.-T.); \\ Tel.: +44-148-368-6597 (T.R.R.)
}

Received: 13 November 2020; Accepted: 5 December 2020; Published: 7 December 2020

check for updates

\begin{abstract}
Solid oxide fuel cells can operate with carbonaceous fuels, such as syngas, biogas, and methane, using either internal or external reforming, and they represent a more efficient alternative to internal combustion engines. In this work, we explore, for the first time, an alumina membrane containing straight, highly packed $(461,289 \mathrm{cpsi})$, parallel channels of a few micrometers $(21 \mu \mathrm{m})$ in diameter as a microreformer. As a model reaction to test the performance of this membrane, the dry reforming of methane was carried out using nickel metal and a composite nickel/ceria as catalysts. The samples with intact microchannels were more resistant to carbon deposition than those with a powdered sample, highlighting the deactivation mitigation effect of the microchannel structure. The coke content in the microchannel membrane was one order of magnitude lower than in the powder catalyst. Overall, this work is a proof of concept on the use of composite alumina membrane as microchannel reactors for high temperature reactions.
\end{abstract}

Keywords: microreformer; dry reforming; microchannel reactor; gadolinium doped ceria; Ni catalyst

\section{Introduction}

Carbon dioxide abatement is one of the biggest challenges of the 21st century, and decarbonizing the transport sector is now a priority for many governments. Solid oxide fuel cells (SOFCs) represent a clean alternative to combustion engines, as they increase the efficiency energy usage of carbon fuels, although they may need external reforming. An external reforming unit may be limited by space, for example, in a vehicle, and therefore solutions to intensify the process are being investigated, for example, using microchannel reactors that can carry out specific reactions in a limited volume. Aiming to further lower $\mathrm{CO}_{2}$ emissions, special attention has been brought to the dry reforming of methane reaction (DRM) (Equation (1)). This reaction has the advantage of utilizing both carbon dioxide and methane, two of the most abundant greenhouse gases. Along with the reverse water gas shift reaction (RWGS) (Equation (2)), which is often a competing reaction, DRM has the potential to produce syngas, and feed a SOFC. Due to the endothermic nature of these reactions, and the high stability of carbon dioxide, high reaction temperatures and a stable catalyst are required to achieve high syngas yields.

$$
\begin{aligned}
& \text { DRM: } \mathrm{CO}_{2}+\mathrm{CH}_{4} \rightleftharpoons 2 \mathrm{CO}+2 \mathrm{H}_{2} \Delta \mathrm{H}^{\circ}{ }_{298 \mathrm{k}}=+247 \mathrm{~kJ} \cdot \mathrm{mol}^{-1} \\
& \text { RWGS: } \mathrm{CO}_{2}+\mathrm{H}_{2} \rightleftharpoons \mathrm{CO}+\mathrm{H}_{2} \mathrm{O} \Delta \mathrm{H}^{\circ}{ }_{298 \mathrm{~K}}=+41.2 \mathrm{~kJ} \cdot \mathrm{mol}^{-1}
\end{aligned}
$$


Investigations, however, have been focused on the performance of catalysts under powder, spheres, or pellet forms when it comes to DRM [1-6]. Few published works report the use of structured catalysts, which are often composed of cordierite honeycombs [7-11], silicon carbide foam [9,12], or stainless steel honeycombs $[13,14]$. These microreactors benefit from rapid heat transfer properties which are particularly relevant for endothermic reactions such as reforming reactions. Unlike for DRM, many studies have been conducted for the steam reforming of alcohols or light hydrocarbons in monolithic reactors [15-20].

In a nutshell, a monolithic reactor is a single compact structure consisting of straight narrow channels that are parallel to each other and allow a facile flow of gas. This configuration of channels offers up to 10 times less pressure drop than randomly packed pellets or spheres in a packed-bed reactor, depending on the channel density [21]. Furthermore, a monolithic structure often offers a higher mechanical strength than catalyst beads, whose breakage involves high operating costs through frequent reformer shutdown and start-up for catalyst reload [22]. When catalyst is coated on the walls of the structure, this system enhances the product's yield and mass transfer effectiveness, due to increased specific surface area, improved heat transfer, and evenly distributed flow [22]. In terms of reforming, microchannel reactors (MCR) have the potential to increase the productivity of the process by limiting the blockage and overpressure risk due to the uncontrolled production of coke, which often occurs in powdered-packed reactors. Indeed, the high reaction temperatures needed often cause catalyst deactivation through active phase sintering. In addition to the deactivation due to the loss of active surface area, large metal clusters favor carbon-forming side reactions, such as methane decomposition, particularly favored at temperatures above $550^{\circ} \mathrm{C}[23,24]$. This causes solid carbon to form on the catalyst, thus physically blocking the active metal phase and, eventually, the reactor. The deactivation of the catalyst does not only decrease the efficiency of the process, but also provokes the formation of hotspots, further damaging the catalyst and the reactor.

Noble metal-based catalysts have shown great activity and high carbon-formation resistance [23,25]. Catalysts based on $\mathrm{Ru}$ and $\mathrm{Rh}$, in particular, show higher activity compared to nickel [13]. However, the low availability and high cost of noble metal is shifting interests towards transition metals. Ni is the go-to metal for both DRM and RWGS [26-28]; however, it is particularly sensitive to carbon deposition in reforming conditions. The strategy for a stable catalyst is, therefore, to form small and well-dispersed Ni particles with strong metal support interactions. Since $\mathrm{CO}_{2}$ is a mildly acidic molecule, a basic support or promoter favors $\mathrm{CO}_{2}$ activation and, therefore, helps coke mitigation [23]. Ceria has been known to drastically enhance the catalytic activity of the catalyst and to reduce carbon formation. Indeed, ceria not only possesses ideal acid/base properties but also provides excellent oxygen mobility, due to its high oxygen storage capacity, thus helping the oxidation of carbon adatoms $[5,29,30]$. The doping of ceria with small amounts of gadolinium is known to enhance the oxygen vacancies concentration in ceria and, thus, improving its oxygen storage capacity [31,32].

The ceramic-based monoliths employed, to this date, for the dry reforming of methane have channel densities between 200 and $400 \mathrm{cpsi}$ [7-10]. With the growing interest towards the miniaturization of reformers for compact and mobile applications, there is a need to develop microreformers. Indeed, fuel cell systems are designed for small-scale applications, and microreformers would enable the onboard production of hydrogen, avoiding the potentially dangerous storage of hydrogen. Llorca et al. have developed a silicon wafer containing over a million microchannels of a few micrometers diameter as a microreactor for the steam reforming of alcohol [33-35]. This high cell density provides increased geometrical surface area per volume, thus increasing the efficiency of the catalyst. However, such pore sizes are quite difficult to manufacture and, subsequently, to coat with a catalyst layer.

In this work we report, for the first time, the use of a composite alumina membrane containing straight, parallel channels of a few micrometers in diameter for the generation of syngas from $\mathrm{CO}_{2}$. The microchannel reactors were fabricated by coating ultrafine $\mathrm{Ce}_{0.9} \mathrm{Gd}_{0.1} \mathrm{O}_{1.95}(\mathrm{CGO})$ particles $(5 \mathrm{~nm})$ with nickel onto the substrate walls. We demonstrate the capability of the membranes to serve as catalyst support, and validate their catalytic activity for the DRM reaction at $850^{\circ} \mathrm{C}$. 


\section{Materials and Methods}

\subsection{Catalyst Coating}

The $\alpha$-alumina ceramic microchannel reactors (MCR) were provided by Smart Separations Ltd. (Guildford, UK). Prior to coating, the MCR were cleaned using a 2\% (v/v) Elma Tec Clean A4 (Elma) in deionized (DI) water solution immersed in an ultrasonic bath for $1 \mathrm{~h}$. The MCR were subsequently dried and heat treated at $500{ }^{\circ} \mathrm{C}$ for $1 \mathrm{~h}$. Two sets of catalysts were produced: a mono-coated Ni on $\mathrm{MCR}$, referred to as Ni/MCR, and a dual-coated MCR with $\mathrm{Ni}$ and $\mathrm{Ce}_{0.9} \mathrm{Gd}_{0.1} \mathrm{O}_{1.95}$ (CGO), referred to as $\mathrm{Ni} / \mathrm{CGO} / \mathrm{MCR}$.

When applicable, the CGO was first coated on the ceramic substrate using the washcoating method. The MCR was immersed in the CGO suspension for $2 \mathrm{~min}$ before drying and heat treatment at $200{ }^{\circ} \mathrm{C}$ for $2 \mathrm{~h}$. The suspension was prepared by mixing $10 \%$ gadolinium-doped ceria particles of $5 \mathrm{~nm}$ average diameter in DI water (50 $\mathrm{mg}$ of nanoparticles/g suspension). The MCR was coated three times to reach a CGO loading of approximately $10 \mathrm{wt} \%$. Nickel particles were coated using a combustion-assisted wet impregnation process. The MCR was immersed in a $1 \mathrm{M}$ nickel nitrate solution for $6 \mathrm{~min}$. The necessary amount of $\mathrm{Ni}\left(\mathrm{NO}_{3}\right)_{2} \cdot 6 \mathrm{H}_{2} \mathrm{O}$ (Sigma-Aldrich, St. Louis, MO, USA) was dissolved in $70 \%(v / v)$ ethanol. A solid form of glycine (Biotech grade; GeneMark) was added as a fuel for the solution combustion with a glycine-to-nitrate molar ratio of 1:2. After immersion, the MCR was dried and calcined at $500{ }^{\circ} \mathrm{C}$ for $1 \mathrm{~h}$. The MCR was coated two times to reach a NiO loading of approximately $10 \mathrm{wt} \%$.

\subsection{Catalyst Characterisation}

$\mathrm{N}_{2}$-adsorption-desorption analysis was performed in a 3Flex apparatus from Micromeritics (Micromeritics Instrument Corporation, Atlanta, GA, USA) at liquid nitrogen temperature. Prior to the analysis, the catalyst was degassed at $250{ }^{\circ} \mathrm{C}$ for $4 \mathrm{~h}$ in vacuum. The surface area was calculated from the Brunauer-Emmett-Teller (BET) equation.

The morphology of the coated MCR was observed by a field emission scanning electron microscope (FESEM, JEOL JSM-7100F, JEOL Benelux, Belgium) at an acceleration voltage of $10 \mathrm{kV}$. The samples were fixed to the holder using carbon paint. After drying, the specimens were subjected to carbon coating prior to conducting microstructural analysis in an Edwards auto 306 coater.

X-ray diffraction (XRD) analysis was conducted on fresh and post test samples using an X'Pert Powder instrument from PANalytical. The diffraction patterns were recorded over a $2 \theta$ range of 10 to $80^{\circ}$. A step size of $0.05^{\circ}$ was used, with a time step of $240 \mathrm{~s}$. Diffraction patterns were recorded at $30 \mathrm{~mA}$ and $40 \mathrm{kV}$, using $\mathrm{Cu} \mathrm{K} \alpha$ radiation $(\lambda=0.154 \mathrm{~nm})$.

Temperature-programmed reduction (TPR) in hydrogen was carried out on the calcined samples in a tubular quartz reactor using a $10 \% \mathrm{H}_{2} /$ Ar gas flow of $50 \mathrm{~mL} \mathrm{~min}^{-1}$, with a heating rate of $10{ }^{\circ} \mathrm{C} \mathrm{min}-1$. Hydrogen consumption was measured by online mass spectrometry (Pfeiffer, OmniStar GSD 320, Pfeiffer Vacuum, Nashua, NH, USA) from room temperature to $900{ }^{\circ} \mathrm{C}$, with a dwell time of $20 \mathrm{~min}$. All samples were dried at $120^{\circ} \mathrm{C}$ under Ar for 15 min prior to each run.

Thermogravimetric analysis (DSC-TGA) was carried out on the samples post catalytic test in a SDT Q600 V8 from TA Instruments (TA Instruments Inc., New Castle, DE, USA). The samples were ramped from room temperature to $900{ }^{\circ} \mathrm{C}$ at $10^{\circ} \mathrm{C} \mathrm{min}^{-1}$ in air.

\subsection{Catalytic Activity}

The catalytic performance tests were carried out in a continuous flow quartz tube reactor (University of Surrey, Guildford, UK) (10 mm ID) at atmospheric pressure. Reactant and product flow compositions were followed by an online gas analyzer (ABB AO2020, ABB, Zürich, Switzerland) equipped with a TCD and a non-dispersive infrared analyzer. The catalysts were tested in powder form supported on a quartz wool bed or in MCR form, fixed in the quartz reactor using PELCO high performance ceramic adhesive (16026-10, Agar Scientific, Stansted, UK). In a typical experiment, $0.2 \mathrm{~g}$ 
of catalyst is reduced in situ at $850{ }^{\circ} \mathrm{C}$ for $1 \mathrm{~h}$ in a $10 \% \mathrm{H}_{2} / \mathrm{N}_{2}(v / v)$ gas mixture. Catalytic reactions were conducted using a total flow of $50 \mathrm{~mL} \mathrm{~min}^{-1}$ composed of reactants diluted in $50 \%$ inert gas $\left(\mathrm{N}_{2}\right)$. The DRM reaction was performed at $850{ }^{\circ} \mathrm{C}$, using a $\mathrm{CH}_{4}: \mathrm{CO}_{2}$ molar ratio of 1 for $40 \mathrm{~h}$.

Conversions of the reactants, as well as the $\mathrm{H}_{2} / \mathrm{CO}$ ratio, were calculated for each run as follows:

$$
\begin{gathered}
\mathrm{X}_{\mathrm{CH} 4}(\%)=100 * \frac{\left[\mathrm{CH}_{4}\right]_{\text {In }}-\left[\mathrm{CH}_{4}\right]_{\text {Out }}}{\left[\mathrm{CH}_{4}\right]_{\text {In }}} \\
\mathrm{X}_{\mathrm{CO} 2}(\%)=100 * \frac{\left[\mathrm{CO}_{2}\right]_{\text {In }}-\left[\mathrm{CO}_{2}\right]_{\text {Out }}}{\left[\mathrm{CO}_{2}\right]_{\text {In }}} \\
\mathrm{H}_{2} / \mathrm{CO}=\frac{\left[\mathrm{H}_{2}\right]_{\text {Out }}}{[\mathrm{CO}]_{\text {Out }}}
\end{gathered}
$$

\section{Results and Discussion}

\subsection{Physicochemical Properties}

The MCR were imaged by SEM and analyzed by EDX after deposition of the catalyst layer. Figure 1 shows typical SEM images of the coated materials, illustrating the high channel density, the regular distribution of channels, and the porosity of the walls, as well as their parallel distribution. Our MCR benefitted from approximately 715 channels $\mathrm{mm}^{-2}$ (or 461,289 cpsi), which far exceeds 200-400 (cpsi) used commonly [7-10,18]. The mean channel diameter was $21 \mu \mathrm{m}$ and about $2.2 \mathrm{~mm}$ long, producing an aspect ratio (depth/width) of about 105, and these can be controlled to lower values (5-100 microns). These allow flexibility in the design of a microreactor, as the volume to area ratio can be modified to fit specific requirements. The pore-wall thickness, on the other hand, was about $5 \mu \mathrm{m}$, but can range up to $15 \mu \mathrm{m}$. As the pores are straight, infiltration of solution or deposition of suspensions is clearly an advantage over high tortuosity catalyst beds, such as randomly packed spheres. However, the fine particle size distribution of the CGO suspension and its low viscosity allowed for the successful deposition of a uniform layer of CGO on the substrate with a thickness lower than $1 \mu \mathrm{m}$ (Figure 1b). The loading of Ni was confirmed by EDX, and nickel dispersion all over the support was witnessed by mapping (Figure S2).
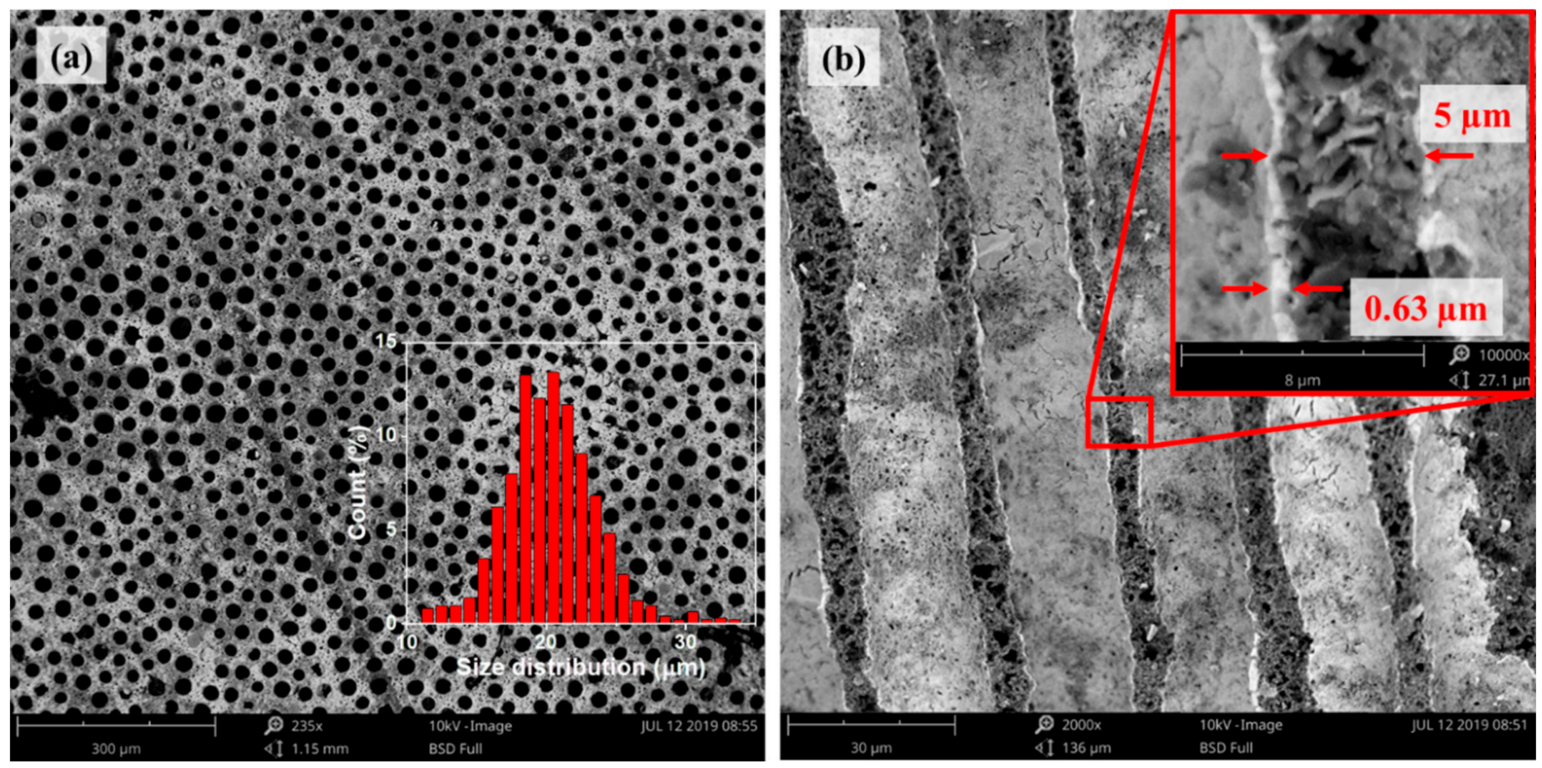

Figure 1. SEM images of $\mathrm{Ni} / \mathrm{Ce}_{0.9} \mathrm{Gd}_{0.1} \mathrm{O}_{1.95}(\mathrm{CGO}) /$ microchannel reactors (MCR) as prepared: (a) top view and pore size distribution and (b) cross-section. No clogging was observed after the infiltration of the catalysts. 
$\mathrm{N}_{2}$ adsorption-desorption isotherms (Figure S1) confirmed that the catalyst layer was mesoporous, presenting a type IV hysteresis loop, while the alumina MCR presents a reversible type II isotherm typical of a nonporous or macroporous adsorbent. The surface areas of the coated monoliths $\left(\sim 11 \mathrm{~m}^{2} \mathrm{~g}^{-1}\right)$ were twenty times larger than that of the uncoated alumina substrate $\left(0.6 \mathrm{~m}^{2} \mathrm{~g}^{-1}\right)$. The high porosity of the catalytic layer is to ensure a proper gas diffusion.

The effective area of the alumina MCR for catalytic testing was $78 \mathrm{~mm}^{2}$, which means about $56 \times 10^{3}$ microchannels. Taking into account the ceramic substrate thickness of $2.2 \mathrm{~mm}$ and the cylindrical shape of the channels, the microchannels yield a total inner surface of $81 \mathrm{~cm}^{2}$ for a total mass of $0.21 \mathrm{~g}$, containing only $0.042 \mathrm{~g}$ of catalyst loading, and a specific inner surface per $\mathrm{m}^{3}$, of $4.69 \times 10^{4} \mathrm{~m}^{2}$ (calculations are detailed in supplementary information).

\subsection{Reducibility}

Temperature-programmed reduction $\left(\mathrm{H}_{2}-\mathrm{TPR}\right)$ was conducted to study the metal-support interaction of the supported $\mathrm{Ni}$ catalysts, their redox properties, and the synergistic effects between $\mathrm{NiO}$ and CGO. The reduction profiles of $\mathrm{Ni} / \mathrm{MCR}, \mathrm{Ni} / \mathrm{CGO} / \mathrm{MCR}$ catalysts, and CGO-coated MCR are shown in Figure 2. The reduction profile of the CGO-coated reactor resembles the typical profile of CGO, displaying a reduction behavior over a large range of temperature and a defined high temperature peak usually attributed to the surface and bulk capping of oxygen, respectively. The large hydrogen intake at low temperature, compared to high temperature, indicates a large amount of surface ceria relative to bulk, which confirms the presence of nanosized ceria particles. The distinction of two peaks at $260^{\circ} \mathrm{C}$ and $420^{\circ} \mathrm{C}$ is attributed to the different environment surrounding $\mathrm{Ce}^{4+}$ [36]. Gd-doping contributes to a weakening of the $\mathrm{Ce}-\mathrm{O}$ bond. The increase in the concentration of surface oxygen vacancies induced by the $\mathrm{Gd}^{3+}$ substitution promotes the adsorption and dissociation of $\mathrm{H}_{2}$, thereby improving the hydrogen consumption at lower temperature.

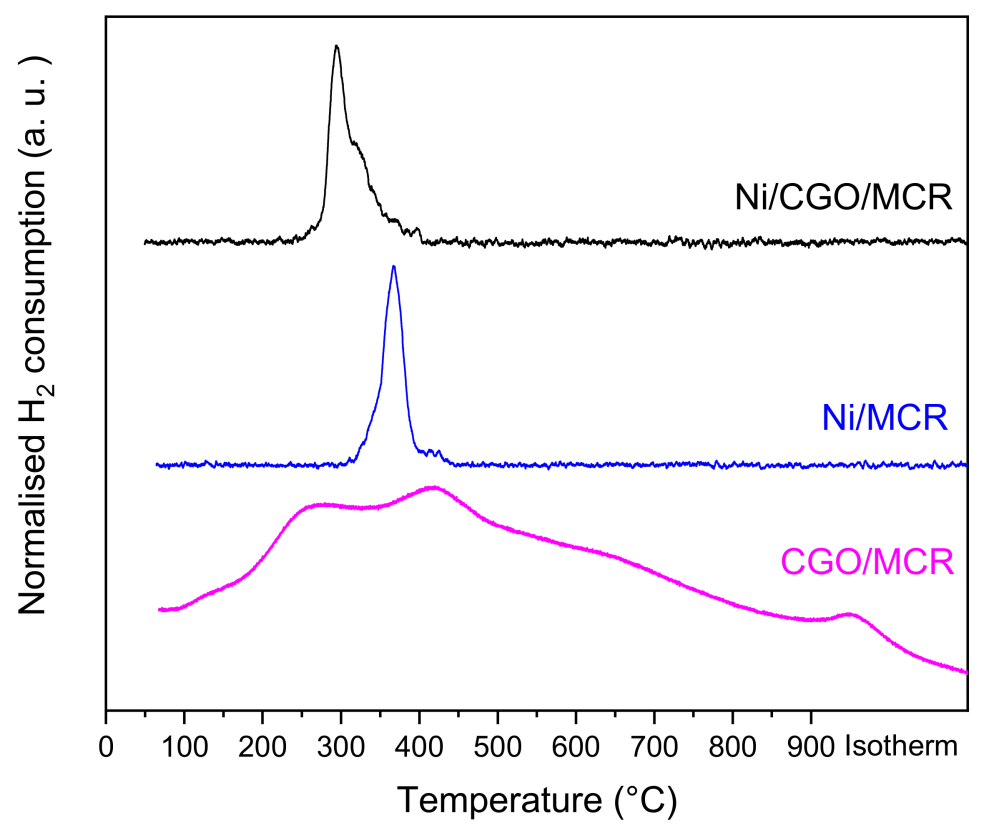

Figure 2. Temperature programmed reduction of $\mathrm{Ni} / \mathrm{CGO} / \mathrm{MCR}, \mathrm{Ni} / \mathrm{MCR}$, and $\mathrm{CGO} / \mathrm{MCR}$.

The Ni/MCR catalyst presents an intensive reduction peak at $365{ }^{\circ} \mathrm{C}$, corresponding to the reduction of bulk $\mathrm{NiO}$ to $\mathrm{Ni}$. There was no $\mathrm{NiAl}_{2} \mathrm{O}_{4}$ spinel formed, as indicated by the absence of high temperature process above $800^{\circ} \mathrm{C}$ and the XRD results. In comparison, the Ni/CGO/MCR sample was reduced at lower temperature as a result of a synergic effect with CGO, acting as an excellent oxygen conductor [37]. This process corresponds to the reduction of bulk $\mathrm{NiO}$ to $\mathrm{Ni}$, as well as the reduction of surface $\mathrm{Ce}^{4+}$ to $\mathrm{Ce}^{3+}$ capping CGO [37]. The reduction happens, however, in two close steps: one at 
$290{ }^{\circ} \mathrm{C}$ and a second one at $320^{\circ} \mathrm{C}$. This may be due to the different interactions between $\mathrm{Ni}$ and the support. Since CGO was coated in the channels of the MCR, and Ni was deposited by impregnation, some Ni particles are located in the walls of the MCR, on the alumina. However, the low porosity and surface area of the MCR offers little relative surface to deposit. Hence, the most intense reduction peak occurs at low temperature and corresponds to the reduction of $\mathrm{NiO}$ in the close vicinity of CGO. This particular configuration allows for one interface terminal oxygen ion of $\mathrm{NiO}$ to spill over between the metal oxide and the support, facilitating the reduction of the metal. This strong affinity between the surface oxygen vacancy of CGO and the interface terminal oxygen ion of $\mathrm{NiO}$ causes the $\mathrm{Ni}=\mathrm{O}$ bond to be weakened. In that case, surface oxygen can oxidize hydrogen at low temperatures $[37,38]$.

\subsection{Catalytic Performance: DRM}

The catalytic performance of the catalysts was first estimated under powder form to assess the catalytic behavior of the materials independently of the microstructure. Figure 3 shows the $\mathrm{CH}_{4}$ and $\mathrm{CO}_{2}$ conversion over time of $\mathrm{Ni} / \mathrm{MCR}$ and $\mathrm{Ni} / \mathrm{CGO} / \mathrm{MCR}$ in powder form. Considering thermodynamics, evaluations predict the maximum conversions to reach 98 and $97 \%$ at $850{ }^{\circ} \mathrm{C}$ for $\mathrm{CH}_{4}$ and $\mathrm{CO}_{2}$, respectively. The Ni/MCR catalyst fails to reach thermodynamic equilibrium conversions; however, the CGO-promoted catalyst closely reaches the equilibrium after $20 \mathrm{~h}$ of reactions for carbon dioxide. The large difference in conversion between the two reactants is an indication that the reverse water gas shift reaction occurs, consuming $\mathrm{CO}_{2}$ and the produced $\mathrm{H}_{2}$ to further produce $\mathrm{CO}$. This recurrently happens in DRM and has been extensively reported [3,5,39]. It is clear here that $\mathrm{Ni} / \mathrm{CGO} / \mathrm{MCR}$ outperforms the Ni mono-coated catalyst. The conversions of the CGO-promoted catalyst are about $20 \%$ greater, highlighting the positive impact of CGO. In fact, CGO is known for its high concentration of oxygen vacancies on the surface, and its optimal redox properties allow for an enhanced $\mathrm{CO}_{2}$ activation, thus increasing the rate of reaction. One must point out, however, the long activation period of the catalysts: both catalysts reach steady state after ca. $20 \mathrm{~h}$ of reaction.

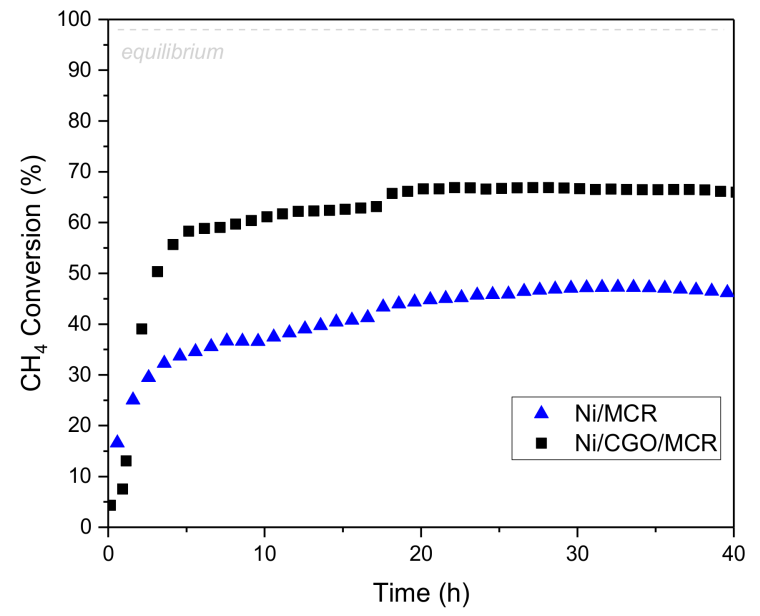

(a)

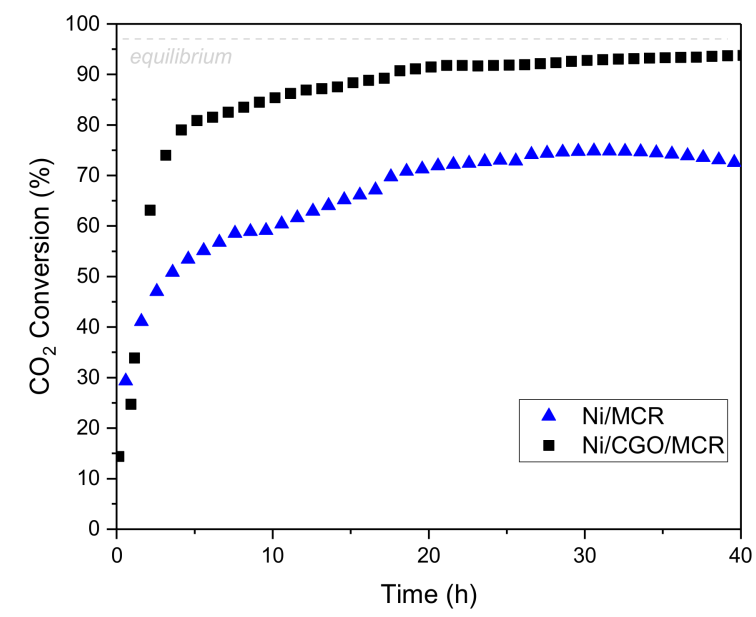

(b)

Figure 3. Catalytic performance of $\mathrm{Ni} / \mathrm{MCR}$ and Ni/CGO/MCR in powder form: conversion of (a) $\mathrm{CH}_{4}$ and (b) $\mathrm{CO}_{2}$.

In view of the powder tests, the $\mathrm{Ni} / \mathrm{CGO}$ catalyst was selected for further testing under MCR form. Figure 4 offers a comparison between the catalytic conversion of $\mathrm{CO}_{2}$ and $\mathrm{CH}_{4}$ by the Ni/CGO/MCR catalyst in powder form and MCR form. The MCR catalyst does not reach the conversions obtained in powder. However, one may note that, although the same mass of catalyst was employed in these tests, the volume of the catalytic bed was four times smaller for MCR. This means that the MCR was reacting at four times the gas hourly space velocity. In addition, the activation time needed for the MCR to reach steady state doubles when operating under MCR form, possibly due to diffusion limitations, 
where reactants may flow using a preferential path through the channels, not entering into contact with the catalyst. The MCR is catalytically active, and a large number of variables can be optimized to increase its performance. First, the microstructure of the monolith: pore size, length, pore size distribution, and even material can be tailor-made. Secondly, the catalyst can also be adjusted: the ratio of $\mathrm{Ni} / \mathrm{CGO}$, the stoichiometry of CGO, and the microstructure of both materials.

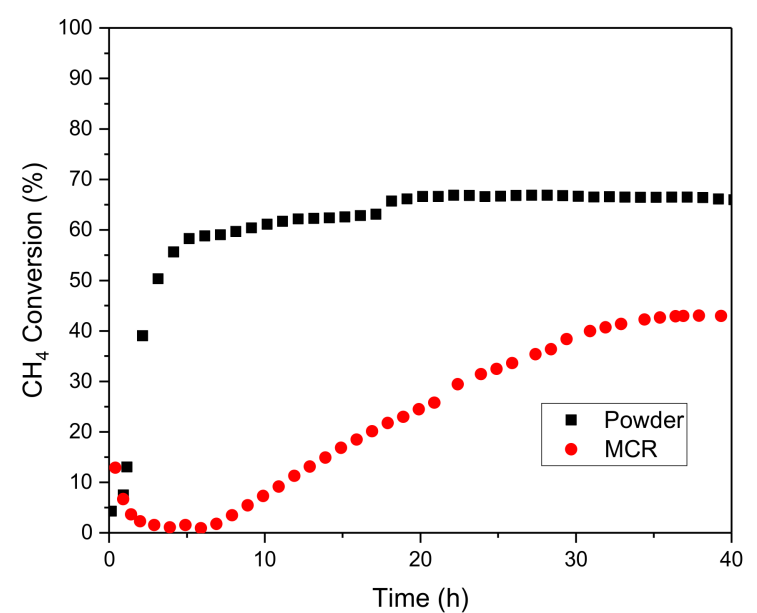

(a)

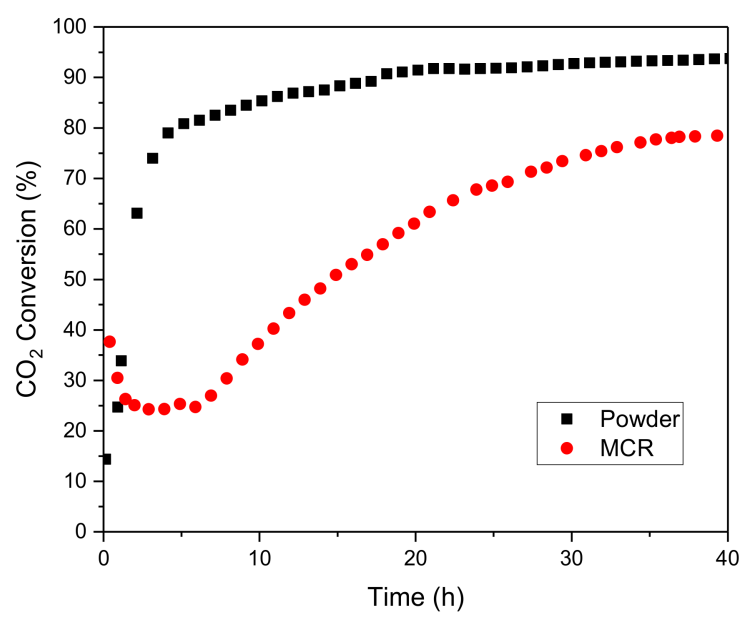

(b)

Figure 4. Catalytic performance of $\mathrm{Ni} / \mathrm{CGO} / \mathrm{MCR}$ in powder form and MCR form: conversion of (a) $\mathrm{CH}_{4}$ and (b) $\mathrm{CO}_{2}$.

\subsection{Characterisation Post Reaction}

The structural variation of the samples after the reaction was followed by XRD. Figures 2 and 5 shows the XRD profiles of Ni/MCR and Ni/CGO/MCR before and after DRM reaction in powder form. All samples present the typical diffraction peak of corundum (ICDD 01-083-2080), which constitutes the MCR. The CGO containing samples present the peaks of cubic fluorite structure of $\mathrm{Ce}_{0.9} \mathrm{Gd}_{0.1} \mathrm{O}_{2}$ (ICDD 01-075-0161). The pre-reaction samples show the typical peaks of NiO (ICDD 00-044-1159), while the samples post reaction show the characteristic peaks of $\mathrm{Ni}$ (ICDD 00-004-0850). NiO peaks are very broad and low in intensity, indicating very small crystallite size. An estimation, using the Scherrer equation, gives $10.2 \mathrm{~nm}$ and $6.8 \mathrm{~nm}$ for Ni/MCR and Ni/CGO/MCR, respectively. The higher surface area provided by the CGO coating, as well as the interactions of $\mathrm{Ni}$ with ceria, led to a better dispersion of $\mathrm{NiO}$. However, after reaction at high temperatures, the resulting $\mathrm{Ni}$ features appear much more intense and narrow, indicating that the catalysts suffered from sintering. Crystallite sizes were estimated at $68.1 \mathrm{~nm}$ and $52.7 \mathrm{~nm}$ for $\mathrm{Ni} / \mathrm{MCR}$ and $\mathrm{Ni} / \mathrm{CGO} / \mathrm{MCR}$, respectively. In addition, the same phenomenon is observed for the CGO crystal phase, but to a lower extent, going from $5.7 \mathrm{~nm}$ to $16.7 \mathrm{~nm}$ after reaction, showing the relative stability of CGO. Moreover, after reaction, a peak at around 26 degrees appears, corresponding to the deposition of carbon, more intense in the sample without CGO. 


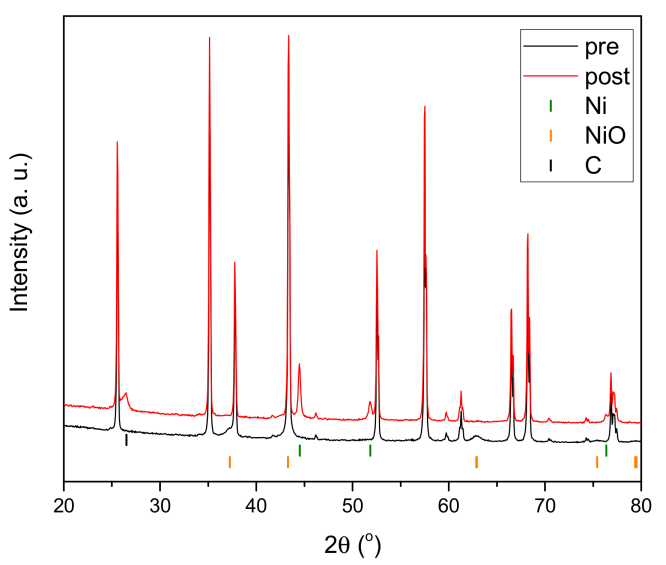

(a)

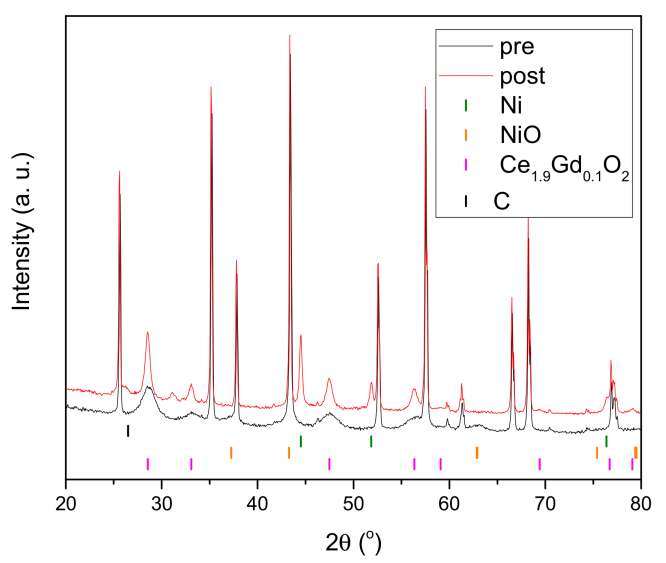

(b)

Figure 5. XRD profiles of the samples pre- and post-dry reforming of methane (DRM) reaction in powder form: (a) Ni/MCR and (b) Ni/CGO/MCR.

Although no deactivation was observed, the formation of carbonaceous species is inevitable when performing DRM. Indeed, an essential step of the reaction mechanism is the dissociation of methane on the metal site to hydrogen adatoms and carbon [40]. The successful gasification of adsorbed $C$ to $\mathrm{CO}$ depends on the catalyst oxygen mobility and $\mathrm{CO}_{2}$ activation capability. The agglomeration of carbon can lead to the formation of inactive carbide, carbon filament covering the catalyst surface, or the nucleation of carbon nanotubes between the support and the metal cluster, thus separating the metal from the catalyst.

Since traces of carbon were detected in XRD on the powder materials, a thermogravimetric analysis was conducted on the reacted samples to estimate the quantity of coke formed during the reaction, and results are shown in Figure 6. In general, two phenomena can be observed, a weight gain due to the oxidation of the sample, and a weight loss corresponding to the oxidation of coke. However, in the case of the microchannel reactor, a weight loss is observed at $312{ }^{\circ} \mathrm{C}$, corresponding to a mildly exothermic reaction, after dehydration of the sample. This likely corresponds to the oxidation of carbonaceous species, although the low temperature indicates that this carbon is quite amorphous, and easily desorbed. Researchers have described three types of carbonaceous species formed during DRM, which are designated as $C_{\alpha}, C_{\beta}$, and $C_{\gamma}[41,42]$. $C_{\alpha}$ denotes the active species responsible for the formation of $\mathrm{CO}$, while $\mathrm{C}_{\gamma}$ is the most inactive species and is responsible for catalyst deactivation. The completely dehydrogenated carbon $\mathrm{C}_{\alpha}$ is a very active and important intermediate in the carbon dioxide reforming with methane. The low temperature weight loss observed hence indicates that the $\mathrm{Ni} / \mathrm{CGO} / \mathrm{MCR}$ sample mostly contains $\mathrm{C}_{\alpha}$ species, and the absence of high temperature weight loss shows the limited presence of $\mathrm{C}_{\gamma}$ coke precursors. The second phenomenon, occurring at around $480{ }^{\circ} \mathrm{C}$ and constituting a weight gain of $0.2 \%$, is attributed to the oxidation of $\mathrm{Ni}$ and surface $\mathrm{Ce}^{3+}$ species. In comparison, the samples tested in powder form exhibit larger weight loss at higher temperatures, confirming the positive impact of the MCR structure on coke mitigation. In the powder samples, the beneficial effect of CGO promotion can be witnessed. The CGO-based catalyst contains less carbonaceous species than the non-promoted sample, and they can be gasified at lower temperature due to enhanced $\mathrm{O}$ mobility. 


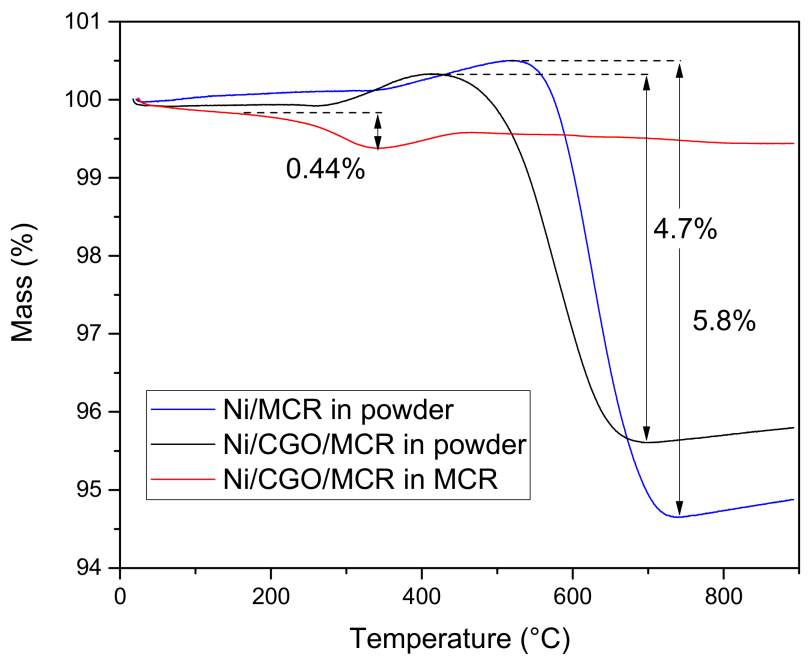

Figure 6. TGA of Ni/MCR and Ni/CGO/MCR after DRM test under powder and MCR form.

Comparatively, the powdered samples were more active than the MCR, hence higher carbon formation is to be expected. The carbon content measured on the MCR remain, however, extremely low, and may be attributed to its configuration. Indeed, in MCR form, the preferential path for the reactants is through the channels where the CGO is coated. Nickel, on the other hand, is present throughout the ceramic, including in the walls. This nickel is not in contact with CGO, as seen in TPR, and is susceptible to coke. In MCR, the probability of the reactants to interact with this nickel is lowered by the configuration, whereas in powder form all nickel species are accessible. This is supported by the $\mathrm{H}_{2} / \mathrm{CO}$ ratio produced and shown in Figure S3. In powder form, the $\mathrm{H}_{2} / \mathrm{CO}$ ratio level is around 1.3, which suggests the strong occurrence of the methane decomposition reaction producing hydrogen and coke. In contrast, in MCR form, the $\mathrm{H}_{2} / \mathrm{CO}$ ratio is lower than 1 , and stabilizes around 1, indicating the partial mitigation of methane cracking.

The MCR after reaction was further analyzed by SEM, and images are shown in Figure 7. The MCR maintained its morphology throughout the test, highlighting the mechanical and thermal stability of the MCR and its suitability for high-temperature operations. The catalyst layer remained intact, apart from some agglomeration due to temperature; no detachment occurred. From the SEM images, no filamentous carbon nor whiskers were observed on the surface of the catalyst, in good agreement with the DSC-TGA results.

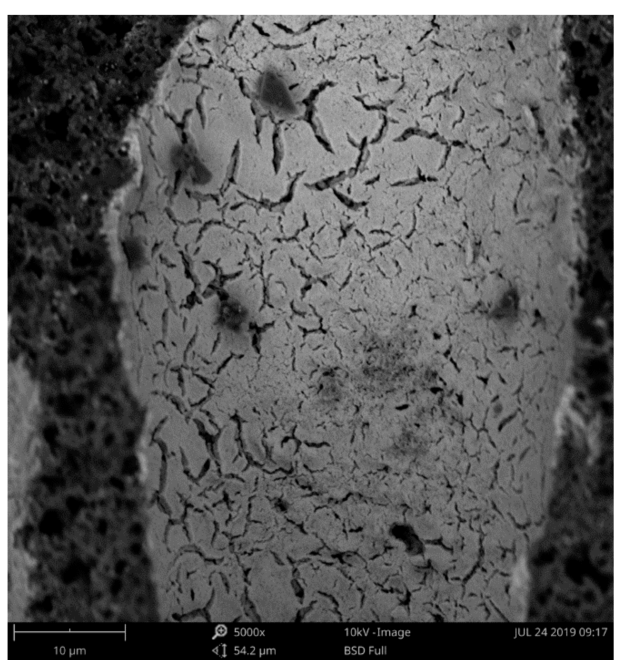

(a)

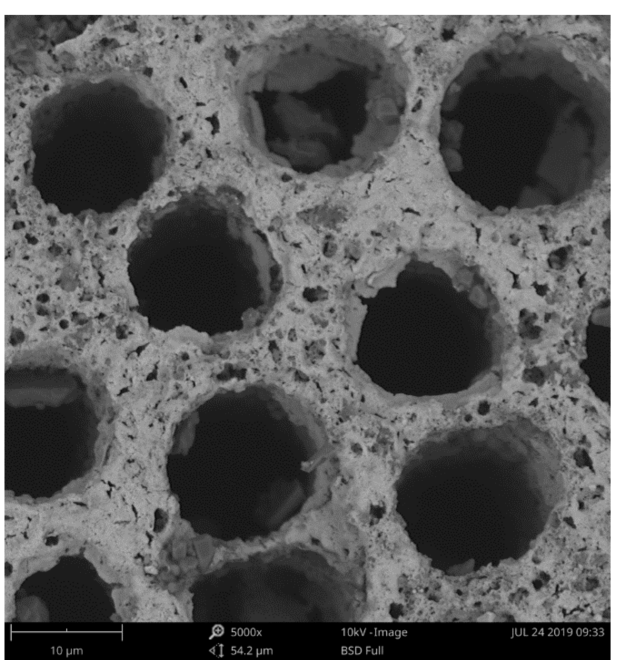

(b)

Figure 7. SEM images of Ni/CGO/MCR after DRM test under MCR form: (a) cross-section and (b) top view. 


\section{Conclusions}

In this work, a composite alumina membrane containing straight, high-density (461,289 cpsi), parallel channels of a few micrometers in diameter $(21 \mu \mathrm{m})$ was used as a microreformer for syngas production. The microchannel reactor was coated with a thin layer of nanosized gadolinium-doped ceria and impregnated with Ni. First, the impact of gadolinium-doped ceria on the activity of the catalyst was investigated. $\mathrm{Ce}_{0.9} \mathrm{Gd}_{0.1} \mathrm{O}_{1.95}$ was found to enhance reactants' conversion by about $20 \%$, while decreasing coke formation. The enhanced performance of the catalyst is most likely due to the exceptional redox properties of $\mathrm{Ce}_{0.9} \mathrm{Gd}_{0.1} \mathrm{O}_{1.95}$, as seen with TPR. Second, the effect of structuring the catalyst was investigated. The MCR displayed lower conversion than the powder catalyst, but this was attributed to the much higher gas hourly space velocity subjected to the MCR. In fact, TGA results showed that no carbon deposition occurred during a 40-h stability test. Despite sintering of the active phase, the catalysts showed no noticeable signs of deactivation, indicating its suitability for continuous $\mathrm{H}_{2}$ production runs.

Overall, the Ni/CGO/MCR catalyst exhibited highly effective conversions of both $\mathrm{CO}_{2}$ and $\mathrm{CH}_{4}$, at temperatures matching SOFC operation conditions. A nonporous support was used for the catalyst which, after washcoating, displayed very low, but increased, specific surface area. Upon structuring, the catalytic MCR had a total mass of $0.21 \mathrm{~g}$, containing only $0.042 \mathrm{~g}$ of catalyst loading, and a specific inner surface per $\mathrm{m}^{3}$, of $4.69 \times 10^{4} \mathrm{~m}^{2}$. After $40 \mathrm{~h}$ under reaction conditions, SEM analyses showed that the channels were not blocked due to carbon deposition, nor did the catalyst layer detach. These results demonstrate the feasibility of using a catalytic alumina membrane as microreformers to generate hydrogen, in order to power portable fuel cells.

Supplementary Materials: The following are available online at http://www.mdpi.com/1996-1073/13/23/6472/s1, Calculation details. Figure S1: $\mathrm{N}_{2}$ adsorption-desorption isotherms of MCR, CGO/MCR, and Ni/CGO/MCR . Figure S2: SEM-EDX mapping of Ni/MCR in powder. Figure S3: Products distribution for (a) Ni/MCR and $\mathrm{Ni} / \mathrm{CGO} / \mathrm{MCR}$ in powder form and (b) Ni/CGO/MCR in powder and MCR form.

Author Contributions: Conceptualization: T.R.R. and E.R.-T.; methodology: E.1.S. and E.R.-T.; investigation: P.T. and E.1.S.; writing - original draft preparation: E.1.S.; review and editing: T.R.R. and E.R.-T.; supervision: T.R.R. and E.R.-T.; funding acquisition: T.R.R. and E.R.-T. All authors have read and agreed to the published version of the manuscript.

Funding: This research was funded by EPSRC Impact Acceleration Account, the Royal Society of Chemistry Industrial Placement awarded to Smart Separations Ltd.

Acknowledgments: Thanks to Hugo Macedo and the R \& D team at Smart Separations for early access to their technology.

Conflicts of Interest: The authors declare no conflict of interest.

\section{References}

1. Arora, S.; Prasad, R. An overview on dry reforming of methane: Strategies to reduce carbonaceous deactivation of catalysts. RSC Adv. 2016, 6, 108668-108688. [CrossRef]

2. Pakhare, D.; Spivey, J. A review of dry $\left(\mathrm{CO}_{2}\right)$ reforming of methane over noble metal catalysts. Chem. Soc. Rev. 2014, 43, 7813-7837. [CrossRef] [PubMed]

3. Le Saché, E.; Johnson, S.; Pastor-Pérez, L.; Amini Horri, B.; Reina, T.R. Biogas Upgrading Via Dry Reforming Over a Ni-Sn/ $\mathrm{CeO}_{2}-\mathrm{Al}_{2} \mathrm{O}_{3}$ Catalyst: Influence of the Biogas Source. Energies 2019, 12, 1007. [CrossRef]

4. Le Saché, E.; Pastor-Pérez, L.; Garcilaso, V.; Watson, D.J.; Centeno, M.A.; Odriozola, J.A.; Reina, T.R. Flexible syngas production using a $\mathrm{La}_{2} \mathrm{Zr}_{2-\mathrm{x}} \mathrm{Ni}_{\mathrm{x}} \mathrm{O}_{7-\delta}$ pyrochlore-double perovskite catalyst: Towards a direct route for gas phase $\mathrm{CO}_{2}$ recycling. Catal. Today 2019, 357, 583-589. [CrossRef]

5. Le Saché, E.; Santos, J.L.; Smith, T.J.; Centeno, M.A.; Arellano-Garcia, H.; Odriozola, J.A.; Reina, T.R. Multicomponent $\mathrm{Ni}-\mathrm{CeO}_{2}$ nanocatalysts for syngas production from $\mathrm{CO}_{2} / \mathrm{CH}_{4}$ mixtures. J. CO2 Util. 2018, 25, 68-78. [CrossRef]

6. Stroud, T.; Smith, T.J.; le Saché, E.; Santos, J.L.; Centeno, M.A.; Arellano-Garcia, H.; Odriozola, J.A.; Reina, T.R. Chemical $\mathrm{CO}_{2}$ recycling via dry and bi reforming of methane using $\mathrm{Ni}-\mathrm{Sn} / \mathrm{Al}_{2} \mathrm{O}_{3}$ and Ni-Sn/CeO$-\mathrm{Al}_{2} \mathrm{O}_{3}$ catalysts. Appl. Catal. B 2018, 224, 125-135. [CrossRef] 
7. Kohn, M.P.; Castaldi, M.J.; Farrauto, R.J. Auto-thermal and dry reforming of landfill gas over a $\mathrm{Rh} / \gamma \mathrm{Al}_{2} \mathrm{O}_{3}$ monolith catalyst. Appl. Catal. B 2010, 94, 125-133. [CrossRef]

8. Luisetto, I.; Sarno, C.; De Felicis, D.; Basoli, F.; Battocchio, C.; Tuti, S.; Licoccia, S.; Di Bartolomeo, E. $\mathrm{Ni}$ supported on $\gamma-\mathrm{Al}_{2} \mathrm{O}_{3}$ promoted by $\mathrm{Ru}$ for the dry reforming of methane in packed and monolithic reactors. Fuel Process. Technol. 2017, 158, 130-140. [CrossRef]

9. Kim, H.; You, Y.-W.; Heo, I.; Chang, T.-S.; Hong, J.S.; Lee, K.B.; Suh, J.K. Development of Monolithic Catalyst System with Co-Ru-Zr for $\mathrm{CO}_{2}$ (dry) Reforming of Methane: Enhanced Coke Tolerance. Clean Technol. 2017, 23, 314-324.

10. Leba, A.; Yıldırım, R. Determining most effective structural form of nickel-cobalt catalysts for dry reforming of methane. Int. J. Hydrogen Energy 2020, 45, 4268-4283. [CrossRef]

11. Soloviev, S.O.; Kapran, A.Y.; Orlyk, S.N.; Gubareni, E.V. Carbon dioxide reforming of methane on monolithic $\mathrm{Ni} / \mathrm{Al}_{2} \mathrm{O}_{3}$-based catalysts. J. Nat. Gas Chem. 2011, 20, 184-190. [CrossRef]

12. Gao, X.; Liu, G.; Wei, Q.; Yang, G.; Masaki, M.; Peng, X.; Yang, R.; Tsubaki, N. Carbon nanofibers decorated SiC foam monoliths as the support of anti-sintering Ni catalyst for methane dry reforming. Int. J. Hydrogen Energy 2017, 42, 16547-16556. [CrossRef]

13. Fukuhara, C.; Hyodo, R.; Yamamoto, K.; Masuda, K.; Watanabe, R. A novel nickel-based catalyst for methane dry reforming: A metal honeycomb-type catalyst prepared by sol-gel method and electroless plating. Appl. Catal. A 2013, 468, 18-25. [CrossRef]

14. Wang, K.; Li, X.; Ji, S.; Huang, B.; Li, C. Preparation of Ni-Based Metal Monolithic Catalysts and a Study of Their Performance in Methane Reforming with $\mathrm{CO}_{2}$. ChemSusChem 2008, 1, 527-533. [CrossRef]

15. Zhai, X.; Cheng, Y.; Zhang, Z.; Jin, Y.; Cheng, Y. Steam reforming of methane over Ni catalyst in micro-channel reactor. Int. J. Hydrogen Energy 2011, 36, 7105-7113. [CrossRef]

16. Bobadilla, L.F.; Álvarez, A.; Domínguez, M.I.; Romero-Sarria, F.; Centeno, M.A.; Montes, M.; Odriozola, J.A. Influence of the shape of Ni catalysts in the glycerol steam reforming. Appl. Catal. B 2012, 123-124, 379-390. [CrossRef]

17. Bobadilla, L.F.; Blay, V.; Álvarez, A.; Domínguez, M.I.; Romero-Sarria, F.; Centeno, M.A.; Odriozola, J.A. Intensifying glycerol steam reforming on a monolith catalyst: A reaction kinetic model. Chem. Eng. J. 2016, 306, 933-941. [CrossRef]

18. Ashraf, M.A.; Sanz, O.; Italiano, C.; Vita, A.; Montes, M.; Specchia, S. Analysis of $\mathrm{Ru} / \mathrm{La}-\mathrm{Al}_{2} \mathrm{O}_{3}$ catalyst loading on alumina monoliths and controlling regimes in methane steam reforming. Chem. Eng. J. 2018, 334, 1792-1807. [CrossRef]

19. Katheria, S.; Deo, G.; Kunzru, D. Washcoating of $\mathrm{Ni} / \mathrm{MgAl}_{2} \mathrm{O}_{4}$ Catalyst on FeCralloy Monoliths for Steam Reforming of Methane. Energy Fuels 2017, 31, 3143-3153. [CrossRef]

20. Kawamura, Y.; Ogura, N.; Yamamoto, T.; Igarashi, A. A miniaturized methanol reformer with Si-based microreactor for a small PEMFC. Chem. Eng. Sci. 2006, 61, 1092-1101. [CrossRef]

21. Nijhuis, T.A.; Beers, A.E.W.; Vergunst, T.; Hoek, I.; Kapteijn, F.; Moulijn, J.A. Preparation of monolithic catalysts. Catal. Rev. 2001, 43, 345-380. [CrossRef]

22. Luqmanulhakim, B.; Matthew James, W. Monolithic substrate support catalyst design considerations for steam methane reforming operation. Rev. Chem. Eng. 2018, 34, 481-501.

23. Papadopoulou, C.; Matralis, H.; Verykios, X. Utilization of Biogas as a Renewable Carbon Source: Dry Reforming of Methane. In Catalysis for Alternative Energy Generation; Guczi, L., Erdôhelyi, A., Eds.; Springer: New York, NY, USA, 2012; pp. 57-127.

24. Nikoo, M.K.; Amin, N.A.S. Thermodynamic analysis of carbon dioxide reforming of methane in view of solid carbon formation. Fuel Process. Technol. 2011, 92, 678-691. [CrossRef]

25. Rostrup-Nielsen, J.R. Aspects of $\mathrm{CO}_{2}$-reforming of Methane. In Studies in Surface Science and Catalysis; Curry-Hyde, H.E., Howe, R.F., Eds.; Elsevier: Amsterdam, The Netherlands, 1994; Volume 81, pp. $25-41$.

26. Rodrigues, M.T.; Zonetti, P.C.; Alves, O.C.; Sousa-Aguiar, E.F.; Borges, L.E.P.; Appel, L.G. RWGS reaction employing Ni/Mg(Al,Ni)O-The role of the O vacancies. Appl. Catal. A 2017, 543, 98-103. [CrossRef]

27. Yang, L.; Pastor-Pérez, L.; Gu, S.; Sepúlveda-Escribano, A.; Reina, T.R. Highly efficient Ni/CeO $\mathrm{C}_{2}-\mathrm{Al}_{2} \mathrm{O}_{3}$ catalysts for $\mathrm{CO}_{2}$ upgrading via reverse water-gas shift: Effect of selected transition metal promoters. Appl. Catal. B 2018, 232, 464-471. [CrossRef]

28. Li, S.; Gong, J. Strategies for improving the performance and stability of Ni-based catalysts for reforming reactions. Chem. Soc. Rev. 2014, 43, 7245-7256. [CrossRef] 
29. Ramirez Reina, T.; Alvarez Moreno, A.; Ivanova, S.; Odriozola Gordón, J.A.; Centeno Gallego, M.Á. Influence of Vanadium or Cobalt Oxides on the CO Oxidation Behavior of $\mathrm{Au} / \mathrm{MO}_{\mathrm{x}} / \mathrm{CeO}_{2}-\mathrm{Al}_{2} \mathrm{O}_{3}$ Systems. ChemCatChem 2012, 4, 512-520. [CrossRef]

30. Reina, T.; Papadopoulou, E.; Palma, S.; Ivanova, S.; Centeno, M.; Ioannides, T.; Odriozola, J.A. Could an efficient WGS catalyst be useful in the CO-PrOx reaction? Appl. Catal. B 2014, 150, 554-563. [CrossRef]

31. Gurav, H.R.; Dama, S.; Samuel, V.; Chilukuri, S. Influence of preparation method on activity and stability of Ni catalysts supported on Gd doped ceria in dry reforming of methane. J. CO2 Util. 2017, 20, 357-367. [CrossRef]

32. Ruiz-Trejo, E.; Sirman, J.; Baikov, Y.M.; Kilner, J. Oxygen ion diffusivity, surface exchange and ionic conductivity in single crystal Gadolinia doped Ceria. Solid State Ion. 1998, 113, 565-569. [CrossRef]

33. Llorca, J.; Casanovas, A.; Trifonov, T.; Rodríguez, A.; Alcubilla, R. First use of macroporous silicon loaded with catalyst film for a chemical reaction: A microreformer for producing hydrogen from ethanol steam reforming. J. Catal. 2008, 255, 228-233. [CrossRef]

34. Divins, N.J.; Trifonov, T.; Rodríguez, Á.; Llorca, J. A Million-Microchannel Multifuel Steam Reformer for hydrogen production. Catal. Today 2020, in press. [CrossRef]

35. Pla, D.; Salleras, M.; Morata, A.; Garbayo, I.; Gerbolés, M.; Sabaté, N.; Divins, N.J.; Casanovas, A.; Llorca, J.; Tarancón, A. Standalone ethanol micro-reformer integrated on silicon technology for onboard production of hydrogen-rich gas. Lab Chip 2016, 16, 2900-2910. [CrossRef] [PubMed]

36. Florea, M.; Postole, G.; Matei-Rutkovska, F.; Urda, A.; Neaţu, F.; Massin, L.; Gelin, P. Influence of Gd and Pr doping on the properties of ceria: Texture, structure, redox behaviour and reactivity in $\mathrm{CH}_{4} / \mathrm{H}_{2} \mathrm{O}$ reactions in the presence of $\mathrm{H}_{2}$ S. Catal. Sci. Technol. 2018, 8, 1333-1348. [CrossRef]

37. Zhao, P.; Qin, F.; Huang, Z.; Sun, C.; Shen, W.; Xu, H. Morphology-dependent oxygen vacancies and synergistic effects of $\mathrm{Ni} / \mathrm{CeO}_{2}$ catalysts for $\mathrm{N}_{2} \mathrm{O}$ decomposition. Catal. Sci. Technol. 2018, 8, 276-288. [CrossRef]

38. Dow, W.-P.; Wang, Y.-P.; Huang, T.-J. Yttria-Stabilized Zirconia Supported Copper Oxide Catalyst: I. Effect of Oxygen Vacancy of Support on Copper Oxide Reduction. J. Catal. 1996, 160, 155-170. [CrossRef]

39. le Saché, E.; Pastor-Pérez, L.; Watson, D.; Sepúlveda-Escribano, A.; Reina, T.R. Ni stabilised on inorganic complex structures: Superior catalysts for chemical $\mathrm{CO}_{2}$ recycling via dry reforming of methane. Appl. Catal. B 2018, 236, 458-465. [CrossRef]

40. Guharoy, U.; Le Saché, E.; Cai, Q.; Reina, T.R.; Gu, S. Understanding the role of Ni-Sn interaction to design highly effective $\mathrm{CO}_{2}$ conversion catalysts for dry reforming of methane. J. CO2 Util. 2018, 27, 1-10. [CrossRef]

41. Xu, J.; Zhou, W.; Wang, J.; Li, Z.; Ma, J. Characterization and Analysis of Carbon Deposited during the Dry Reforming of Methane over Ni/La $\mathrm{O}_{3} / \mathrm{Al}_{2} \mathrm{O}_{3}$ Catalysts. Chin. J. Catal. 2009, 30, 1076-1084. [CrossRef]

42. Guo, J.; Lou, H.; Zheng, X. The deposition of coke from methane on a Ni/MgAl ${ }_{2} \mathrm{O}_{4}$ catalyst. Carbon 2007, 45, 1314-1321. [CrossRef]

Publisher's Note: MDPI stays neutral with regard to jurisdictional claims in published maps and institutional affiliations.

(C) 2020 by the authors. Licensee MDPI, Basel, Switzerland. This article is an open access article distributed under the terms and conditions of the Creative Commons Attribution (CC BY) license (http://creativecommons.org/licenses/by/4.0/). 